\title{
Research on College Students' Ideological Trend from the Perspective of Ideological and Political Education in Institutions of Higher Learning
}

\author{
Li Shiyang \\ School of Management Science and Engineering \\ Shandong Technology and Business University \\ Yantai, Shandong 264005 \\ 291519686@qq.com
}

\begin{abstract}
It is found out from the investigation that college students' ideological trend has shown some new characteristics. They pay attention to events at home and abroad including the Party's meetings, national laws and regulations, employment orientation and so forth. They are positive in ideological understanding and hold optimistic attitude toward life. And they have raised their subject consciousness, sense of participation and responsibility, especially in employment and job-choice. Of course, they still confront with some confusions and difficulties, for example, they take no interest in professional learning and are unclear of employment orientation and career planning, in the aspect of which they show diversified ideological trend. The reason why they have shown such trend is that it is inseparable from rapid development of modern society. The current new thing and rapid change have decided their ideological trend. Therefore, this paper aims to strengthen college students ideological and political education through deepening theoretical study and education, intensifying their ethic education, widely developing social practice activities and volunteering services activities, organizing varied and colorful campus cultural activities, actively promoting their employment and entrepreneurship and caring for and serving students with financial difficulties. And the paper has proposed that it should strengthen ideological guidance, deepen their sense of identify on socialist core values, conduct ideal and belief education, guide them to build values and realize their life ideals, integrate "three loves" and "three frugalness" education to promote the influence of Chinese traditional virtues and actively make the most of Internet to expand the effectiveness of ideological and political education.
\end{abstract}

Keywords-ideological and political education, college students, ideological trend

\section{NEW CHARACTERISTICS OF COLLEGE STUDENTS} IDEOLOGICAL TREND

Ideological trend refers to the development and change of cognitive results produced by human thinking activities. College students are a special intellectual group in society. Their ideological trend has a direct influence on the formation and development of their morally sound values and outlook on the world and life. Their cognitive attitude and opinions on emotion, study, employment and various sectors of society have also a direct bearing on their behaviors and decision- making in society. How to change college students' some unsound ideology and behaviors in order to promote them to develop and grow more healthily has become an urgent need to address the issue for college students' ideological and political education, or even the workers of ideological and political education in current institutions of higher learning.

\section{A. Focusing on domestic and international issues}

The investigation shows that since the 18th CPC National Congress, most college students pay high attention to events relating to national interests and show strong patriotism and national confidence. They pay close attention to national safety and security and hold rational attitude toward social new things, showing relatively strong logic analysis capability. They highly recognize scientific outlook on development, strategic goal of socialist harmonious society, "Two Centenary Goals" and Chinese Dream and approve major development strategies and measures such as building a new socialist countryside and targeted poverty alleviation. Only a very smallest percentage of students are indifferent. An excellent college student should not only possess solid professional knowledge, but also pay close attention to national issues and improve his/her awareness in politics, overall situation, core and conformity. Only by doing so can he/she be cultivated sense of responsibility[1].

\section{B. Diversified behavior choice}

Behavior is conscious and purposeful activity of human being. General speaking, the mind governs people's behavior which can deepen the mind in reverse. In new era, the society has experienced rapid and huge change. Due to increased choices, college students show diversified tendency in choice behavior. But it must understand such phenomenon correctly. The feasible and effective way is to make college students build correct ideological concept and awareness through ideological and political education, thus making them form correct code of conduct.

\section{Diversified outlooks on values}

From this investigation, the subject consciousness of college students has been intensified. Most students can think independently and hold their own understanding and attitude toward issues. With economic development and social 
improvement, college students have unique personalities and high comprehensive quality. But their psychological endurance is poor on the whole.

\section{Emphasis on employment and job choice}

The most important factors influencing on college students' job choice are" wage income", "personal development" and " work place--whether it is medium or large-size cities or highly developed district", followed by "majors--whether they match with jobs" and "parents expectation", then by "the needs of country". They are generally unoptimistic toward employment prospect and feel the pressure of employment[2].

The main reason why college students are unoptimistic toward employment prospect is that the contrast between high social demand for talents and students' professional strength, which makes part of students lack of confidence and competitiveness, thus afraid to face the music. Nowadays, with the rapid development of science and technology and everincreasing fierce competition, the talents that society demands are those high quality talents who are able to adapt to the requirements of the era of knowledge-driven economy. Such talents should acquire solid professional knowledge, comprehensive knowledge structure, sound ideology and morality, healthy mindset, sound personality and creativity. But under the intense competition for talents, a majority of students lack confidence, which is due to the lack of work strength and competitiveness. They either lack solid professional foundation and have limited knowledge or are psychologically handicapped without creativity and dedication spirit.

\section{REASONS THAT AFFECT COLLEGE STUDENTS' IDEOLOGY}

For a long time, unified requirement and guidance on college students without any particular treatment disconnect knowledge and action and make them confused and lost in their ideology in the process of ideological and political education in institutions of higher learning, especially in ideological and political teaching. We maintain that as for the problems in their ideology and action, it should clarify the nature of problems with particular treatment. With respect to political problems, it should solve them timely and resolutely. With regard to ideological problem, the main way is persuasion education. As for problems of perception, the key is to emancipate the mind. And for the problems of their actual interests, the main way is to persuade and resolve in a careful manner. Only by doing so can students be guided to gradually make progress in ideological and political quality, thus reaching the desired educational objectives. Since the ideological and political education is paid little attention to for a long time and in terms of working style, past experiences and old methods, channel, fronts and carriers are not suitable for the needs of ideological and political education in new situation, thus we should emancipate mind and build creative concepts in order to continuously explore new ones in the ideological and political education in the new era[3].

\section{WAYS TO STRENGTHEN COLLEGE STUDENTS IDEOLOGICAL AND POLITICAL EDUCATION}

\section{A. It should deepen educational activities for theoretical study.}

At present, we should make great efforts to strengthen the education in socialist outlook on politics for colleges' students, the core of which is ideal and faith education. Firstly, it should use mass media in a proper way to create sound public opinion environment, especially in the influence and penetration of ideological and political education. From this investigation, it shows that the main way for college students to acquire social information is through domestic newspaper, television and Internet. We should not only strengthen management and guidance, but also use them in a proper way and make the most of their positive influence and inhibit their negative influence. Secondly, it should unremittingly undertake "studies on the theoretical and practical issues of Party building", arm and educate students with scientific theories, construct strong spirit pillar, guide them to build high hopes and be firmly committed to following the party's path of socialism with Chinese characteristics, further strengthen the sense of honor and pride of students' Party and League member and help them clarify their historical mission and social responsibility. In addition, it should organize and conduct educational activities on current situation and policies, aim at hot issues that students take interest in to help them get a clear understanding of domestic and international situation and educate and guide them to understand Party's guidelines and policies comprehensively and precisely and actively devote to the construction of modernization. Moreover, it should widely conduct patriotic educational activities concerning promotion national spirit.

\section{B. It should intensify moral education for college students.}

It is shown in the investigation that college students don't have high appraisal on their own moral level and have an unclear understanding of unmoral phenomenon on campus, which reflects the actual situation of college students at present. Thus, in moral education, all teachers in institutions of higher learning should play their roles in teaching, management and service to educate students and carry out moral education in every sector of college work. In addition, it should strengthen college students' moral quality and practice, which can really guide students to start from small things bit by bit, uphold justice and dispel evil, cultivate the sense of justice and responsibility of college students, and improve their moral quality.

\section{It should widely conduct social practice and volunteering services activities}

It should widely promote college students to do teaching practice, social survey, voluntary service, public benefit activities, scientific and technological invention and a part-time job while studying at college. In addition, it should also facilitate them to get to know national conditions and the society, strengthen their faith, and sharpen their will. Moreover, it should educate them in practice in order to help them increase their capabilities and make contribution to the society. During winter and summer vacation, it should organize college 
students to actively take part in social practice such as "Sanxiaxiang" (a program under which officials, doctors, scientist and college students go to the countryside to spread scientific and literacy knowledge and offer medical service to farmers), "Sijin Shequ" (a program under which scientific and technological knowledge, literacy knowledge and entertainment, law and healthy knowledge are spread among districts) and further increase the influence of such activities. It should vigorously promote the building of social practical base. And college students should use holidays and spare times to go into all sectors of society to conduct all kinds of voluntary service activities such as community service, environmental protection, legal publicity and disease prevention. Thus, their sense of social responsibility is cultivated. What's more, it should consolidate "Go West -College Graduates Volunteer Program” to make more graduates take part in this program.

\section{It should organize varied and colorful campus cultural activities.}

It should play the role of the League and student union in various activities concerning science and technology, culture and entertainment, public service, sport, etc. to activate campus culture and combine morality, intelligence and fitness in order to help college students improve their ideological and ethical quality in campus culture activities. It should vigorously create scientific and cultural brand on campus activities and make intensive efforts to conduct scientific and technological innovative activities for the public by taking the "challenge cup" extracurricular academic scientific and technological works competition and entrepreneurship plan competition as the leading role. Furthermore, it should integrate current cultural activities on campus, organize "Campus Cultural Festival for Chinese College Students" and continue to conduct " college student singers competition on campus" in order to make more people know campus cultural activities well. In addition, it should make full use of student union and vigorously support theoretical learning-based associations by holding competitions for excellent associations, exhibition and performance of club activities, etc., encourage them to build academic science and technology-based and hobby-oriented associations and actively promote social public service associations. Meanwhile, it should work for the flourish of these associations and at the same time for management in order to make students associations become an important carrier for college students of "self-education, self-management and self-service", thus forming an important healthy and positive force of campus culture and creating sound campus cultural environment.

\section{E. It should actively promote college students to find jobs and start up business}

It should take great pains to help college students build correct outlook on employment and entrepreneurship, establish the idea of "flexible employment characterized by" putting employment before job choice" and promote them to go the west and to grassroots for employment. It should comprehensively improve their quality in employment and entrepreneurship, build practical base for employment and mobilize more institutions to provide diversified internship positions for different grade students, especially senior students.
In the meantime, it should construct the platform of employment and entrepreneurship between college students and employers. Through such methods as competition of business plan, it can conduct entrepreneurial education, guidance and training so as to create a kind of campus environment for encouraging entrepreneurship.

\section{F. It should care for and serve college students with financial difficulties.}

It should strive for supports from all sectors of society, absorb social resources, increase money sources for helping students with financial difficulties and intensify direct aids and reward students with financial difficulties. Besides, it should build excellent self-improvement models to guide and stimulate more students with financial difficulties to be selfimprovement, self-reliance and work hard to complete their studies smoothly. And it should provide more part-time jobs on campus for students to help them overcome difficulties and finish their studies.

\section{SUGGESTIONS ON STRENGTHENING IDEOLOGICAL AND POLITICAL EDUCATION FOR COLLEGE STUDENTS}

\section{A. It should strengthen ideological guidance and deepen the sense of identity on socialist core value}

Socialist core value is an important navigation mark to guide young people to be progressive and also spiritual flag to promote social progress. Only by organizing study and strengthening guidance can students be motivated to observe and practice it consciously. On the one hand, the workers of ideology and politics in institutions of higher learning should actively organize students to study Opinions on cultivating and practicing socialist core values issued by general office of the CPC central committee, have a comprehensive command of these Opinions, concentrate on students' attention and unify their ideological consensus. On the other hand, colleges should organize special lectures on the theory of socialist core value and Chinese excellent traditional culture in order to have students comprehensively grasp the scientific connotation, significance and practical requirement of core value, have a full understanding of the essence of Chinese culture and stimulate them to think, thus enhancing their cultural identify and sense of responsibility and laying a solid ideological and culture foundation for cultivating and practicing socialist core values.

\section{B. It should carryout ideal and faith education and guide students to build values and realize their life ideals}

Firstly, it should continue to further study the ideological situation of college students, timely and precisely grasp their ideological trend, actively help them solve ideological confusion and difficulties and guide them to grow with firm political commitment. Secondly, it should carry out exchange and communication face-to-face between teachers and students to understand college students' requirement for development, pay close attention to their spiritual appeal, guide them to correctly treat the relationship between ideal and reality and stimulate them to strive for their dreams. Thirdly, it should hold a seminar on the situation and policies on a regular basis in order to promote national guidelines and policies and 
educate students to correctly view social hot issues and the problems in national development so as to reduce the interference of unsound ideology from outside world on students.

\section{It should integrate "three loves" and "three frugalness" education to promote the influence of Chinese traditional virtues}

Institutions of higher learning should actively carry out educational activities such as "three loves" of "loving study, labor and country" and "three frugalness" of "saving food, water and electricity". It should educate student to set up the goal of life-long learning, cultivate them to build the concept of "labor being glory" and deepen patriotism education. It should make the most of rich educational resources of various festivals and memorial days popularize national spirit and zeitgeist and guide college students to feel red classics and inherit revolutionary spirit by taking "red education base" and "red film exhibition" as carriers. In addition, it should deepen the educational activities of "saving food, water and electricity", adhere to conduct "clear your plate" campaign and guide students to take part in the campaign in the form of class meeting, quiz show, debate competition, etc. in order to create the campus cultural atmosphere in which saving is glory and wasting is shameful. In the meantime, it should guide students to practice diligent and frugal social mode and build conservation-oriented campus. Only with our practical action can we build beautiful China.

\section{It should actively make the most of Internet to increase the effectiveness of ideological and political education.}

Institutions of higher learning should take advantage of new media such as Weibo and Wechat to integrate Internet culture with college culture and depend on new media to innovate the ways of opinions guidance and ideological and political education for college students. The workers of ideological and political education should be promoted to build Internet platform in the form of Weibo, Wechat, Renren, etc. by taking glass as a group and conduct their work with various online ways in which young people take interest such as blog, video, social websites, instant communication, forum, etc. Meanwhile, it should integrate traditional culture, classical art and fashion to establish a platform in which information management and supervision are combined with, fill the online front of ideological and political education with positive sound and advanced culture and firmly build the "firewall" in the field of college students' ideology. Students instructor at all grades should adhere to update online contents to make online platform have audience, influence and response and adapt to "micro age" by using "micro education" to make new technologies become an important weapon to promote ideological and political education for college students.

\section{CONCLUSION}

It should take historical background and intergenerational features into full consideration when outlining the characteristics of contemporary college students. It should neither evaluate nor define the group characteristics with staid, rigid and old ways of thinking, nor with "stereotype". General secretary Xi Jinping pointed out in the reports of the 19th CPC National Congress that "a nation will prosper only when its young people thrive; a country will be full of hope and have a great tomorrow only when its younger generations have ideals, ability, and a strong sense of responsibility. The Chinese Dream is a dream about history, the present, and the future. It is a dream of our generation, but even more so, a dream of the younger generations. The Chinese Dream of national rejuvenation will be realized ultimately through the endeavors of young people, generation by generation." Contemporary college students should have strong patriotic consciousness and sense of historical responsibility and dare to express their own voice without flattering foreign countries, having narrow mind, drifting along and putting up with incorrect things. Although we hold a little bit of "lucky", we have the confidence to believe that as one of backbone and elite among young people in Chinese society at present, they must become the pillar of the country and on the basis of highly recognition of national interests and clear understanding of western countries, they must make contribution to the future of the country and national development with open mind and sense of responsibility.

\section{REFERENCE}

[1] Luo Hongtie. Research on Ideological and Political Education[M]. Sichuan People's Publishing House, 2002(In Chinese)

[2] Qu Yanhong. On Modern Development of Mass Communication and Ideological and Political Education for College Students[J]. Journal of Shandong University (Philosophy and Social Science), 2005(In Chinese)

[3] Zhao Hong, Bai Genyuan, Liu Yali. Reflection on the Innovation of Ideological and Political Education in Institutions of Higher Learning in New Situation[J]. Journal of Hebei Institute of Architectural Science \& Technology (Social Science Edition), 2005(2). (In Chinese)

[4] Fan Jianwu, Liu Guanglin. On Challenge and Innovative Practice of Ideological and Political Education for College Students in New Era[J]. Value Engineering,2012( 5) : 222-223. (In Chinese)

[5] Li Weijuan. Survey on College Students' Ideological Trend[J]. Education and Vocation, 2012( 16) : 50-52. (In Chinese)

[6] Zhang Li. Research on Characteristics of Contemporary College Students' Ideological Trend and Coping Strategies for Ideological Education in Institutions of Higher Learn ing[J]. Youth Liberator, 2012 (10): 145, 147. (In Chinese)

[7] Liu Hua. On College Students' Ideological and Moral Education from the Perspective of Socialist Core Value[J]. Education and Vocation, 2015 (2): 68-69. (In Chinese) 